\title{
A FENNTARTHATÓ FEJLŐDÉS ELVEI ÉS AZOK ÉRVÉNYRE JUTÁSA A BANKI GYAKORLATBAN II. rész
}

Az utóbbi évtizedben a környezettudatos gazdálkodás szerepének felértékelôdése új tevékenységi területet nyitott meg a bankok elốtt, amit nemzetközi szóhasználattal élve green banking-nek neveznek. A fenntartható fejlődést támogató projektek banki finanszírozása számos lehetôséget nyit a pénzügyi intézmények számára - hírnév, új ügyfélbázis, kockázatcsökkentés, jövedelmezôség növelése -, amennyiben a bankok a fenntarthatóság elveit megfelelóen integrálják múködési stratégiájukba. A cikksorozat második részében a szerzók a bankok fenntartható múködését támogató külsố és belsố motiváló tényezóit veszik vizsgálat alá, amelyet már nemzetközi elvek és megállapodások is szabályoznak és támogatnak. Kiemelt fontosságot tulajdonítanak a környezettudatos gazdálkodás banki stratégiába történó integrálásának, melynek alapjait teremthetik meg a cikkben vizsgált nemzetközi irányelvek.

Kulcsszavak: fenntartható fejlốdés, zöld bank (green banking), equator elvek, banki stratégia

A fenntartható fejlődés elve, követelményrendszere napjainkban kiemelten fontos szerepet tölt be mind a nemzetközi, mind a nemzeti politikaalkotási folyamatokban és a különböző gazdasági, technológiai, társadalmi, kulturális célkitúzések megfogalmazásának, lehetséges elérési útjainak azonosításában. Ennek oka fóként abban kereshetố, hogy a tudományos közösség, az üzleti élet, a társadalom szereplői, tagjai egyre növekvő mértékben ismerik fel a fenntarthatóságnak, az emberi élet és a természeti környezet jövőbeli egészségének és jólétének biztosításában betöltött jelentőségét. Ugyanakkor fontos azt is megemlítenünk, hogy a fenntartható fejlődés általánosan elfogadott definíciója ez idáig nem került kidolgozásra, illetve a definíciók folyamatos fejlődésen mennek keresztül. A legnépszerúbb definíció a Brundtland Bizottságnak tulajdonítható, mely 1987-ben „Közös Jövônk” címú kiadványában határozta meg a fenntartható fejlódés fogalmát. A kiadvány óta eltelt idóben definíciók tucatjai jelentek meg a fenntartható fejlődésre vonatkozóan, melyek mind arra tettek kísérletet, hogy bemutassák, mit is érthetünk fenntartható fejlődés alatt, és melyek azok a folyamatok, melyek révén elérhetnénk e kívánt állapotot. Az elmúlt évtizedekben publikációk sokasá- ga látott napvilágot, melyek a vállalatok társadalmi és környezeti felelősségével foglalkoznak. Ugyanakkor a pénzügyi intézmények, bankok környezettudatossága viszonylag kevesebb figyelmet kap, melynek oka elsốsorban abban áll, hogy ezek a szervezetek önmagukat alapvetően környezetbarátnak tekintik. Az egyik legnagyobb probléma az, hogy különbség van a vállalati felelősség és a pénzügyi piacok aktuális viselkedése között. Bár egyre több vállalat teszi magáévá a vállalati felelôsséget, a pénzügyi szféra sokáig nem ismerte fel, nem jutalmazta, mert az ma is gyakran rövid távú szempontokat követ.

A pénzügyi szférának egyre jelentôsebb szerepe lehet hitelezési tevékenységén keresztül a fenntartható fejlődésben és a környezetvédelemben, ezt a kapcsolatot, összefüggést jelzi a green banking kifejezés is. A bankok befektetési döntéseiken keresztül, környezetkímélő beruházások támogatásával, nagyban befolyásolhatják a környezet minőségét. Bár nagy környezeti kockázatnak vannak kitéve, a nemzetközi irányelvek kidolgozása és azok banki stratégiába integrálása nemcsak a hátrányok elkerülését segíti, de jelentôs elônyökhöz is juttathatja az ilyen zöld bankokat. 


\section{A bankok szerepe a fenntarthatóság elérésében}

A bankszektor alapvetően két alábbi funkciója révén befolyásolja a gazdasági szereplók életét, tevékenységét, ha a fenntarthatóság oldaláról közelítünk:

- Egyrészt: a bankok gyújtik be a háztartások és vállalatok megtakarításait, és ezeket a megtakarításokat további beruházásokra, hitelkihelyezési tevékenységekre használják fel. Következésképp: a bankok közvetítő szerepet töltenek be, speciális közvetítő piacot képezve a kereslet és kínálat számára.

- Másrészt: a bankok menedzselik, diverzifikálják a múködésükkel kapcsolatos kockázatokat, céljuk e kockázatok minimalizálása.

A pénzügyi intézmények részvétele a fenntartható fejlődés elérésében igen jelentôs, külsô és belsô tevékenységeik révén gyakorolnak hatást a természeti környezetre. A bankok belsố tevékenységeik környezeti hatásai viszonylag kisebbnek mondhatók az ipari szféra szereplóiéhez képest. Ugyanakkor, ha figyelembe vesszük a bankszektor méretét, világossá válik, hogy a bankok által használt energia, víz, papír, illetve a múködés során keletkező hulladék mennyisége nem elhanyagolható.

Általában véve a banki múködés külsố dimenziója sem károsítja a környezetet. A banki termékek és szolgáltatások nem károsítják közvetlen módon a természeti környezetet. Ám ha a bankok beruházási, hitelkihelyezési, kockázatkezelési tevékenységeit vizsgáljuk, akkor megállapítható, hogy a bankok közvetett módon részesülnek a környezetszennyezésból.

A banki zöldülést külsô és belső hajtóerői, tendenciák támogatják. A belső hajtóerôk egy része a banki alkalmazottaktól, shareholderektől, vezetőktől származik, környezettudatosságuk, attitúdjeik, egyéni céljaik, nézeteik meghatározók lehetnek. Emellett a gazdasági célkitüzések, a banki image-építés is ösztönözheti a bankokat arra, hogy elmozduljanak a fenntarthatóság irányába, hiszen a zöld banki termékek és szolgáltatások révén a bankok új piacokra léphetnek be, növelhetik piaci részesedésüket, másrészt csökkenthetik a felelősségi kockázatokat. A külsố hajtóerók között szerepel az állam, a vevók, a versenytársak, illetve a társadalom oldaláról érkező nyomások, elvárások, előírások és kereslet.

Az IFC által 2005-ben végzett felmérés szerint a bankok a következő három cél miatt kötelezik el magukat a fenntarthatóság mellett (IFC, 2005 in: Cattaneo, 2007):

- jó hírnév (a bankok 68\%-ánál áll az elsố helyen),

- beruházói kereslet (64\%, második prioritás),

- kockázatcsökkentés, megtérülés növelése $(52 \%$, harmadik hely).
A pénzügyi intézmények, a bankok, a gazdaság más szereplőihez hasonlatosan, alapvetôen a profitmaximalizálás elve alapján múködnek. Adhatnak ugyan hitelt a cégeknek környezetkíméló technológiákra, figyelembe vehetik a vállalatok fenntarthatóság érdekében tett lépéseit, mindezt lényegében azért teszik, mert ebból nekik is hasznuk származik. Egyrészt növelni tudják profitjukat, másrészt csökkenteni kockázatukat. A felelősség fogalma minden szereplőre kiterjed. Egyrészról ott vannak a vállalatok, melyeknek környezetükkel összhangban, társadalmi megfontolásokat is figyelembe véve kell múködniük. A másik oldalon ott vannak a magas társadalmi és környezeti felelősségérzettel rendelkező emberek, a befektetôk, a betétesek, akik hajlandóak akár alacsonyabb hozamot is elfogadni annak érdekében, hogy pénzük felhasználása ne fokozza a világ pusztítását.

$\mathrm{Az}$ Innovest környezeti minôsítéseket végzô Wall Street-i társaság elemzése igazolni látszik, hogy a környezettudatosság versenyelôny forrása lehet a vállalatok, illetve bankok számára. A társaság ugyanis elemezte a fenntarthatósági szempontokat leginkább figyelembe vevố vállalatok részvényeinek hozamait, és megállapították, hogy a fenntarthatósági szempontokat integráló vállalatok nagyobb növekedést mutattak, mint a fenntarthatósági szempontokat kevésbé vagy egyáltalán nem figyelembe vevő vállalatok (Tóth, 2001).

A vállalatok és befektetốk között elhelyezkedô pénzügyi közvetítók feladata, hogy a felelős befektetók megtakarításait a fenntarthatósági szempontokat is figyelembe vevố vállalatokba invesztálják.

A pénzintézetek a tevékenységükkel kapcsolatos kockázatot kezelik és elosztják. A legfőbb céljuk, hogy minimalizálják a kockázatok bekövetkezésének lehetőségét. A bankok múködésük során a következő három kockázattal biztosan találkoznak: a hitelkockázattal, a biztosíték elértéktelenedésének kockázatával és a közvetlen felelősség kockázatával. A megnövekedett hitelkockázat akkor keletkezik, ha az ügyfelek nem képesek visszafizetni hiteltartozásukat a banknak. Ha magas a kihelyezett összeg és hosszú a lejárati idô, magasabb a kockázat. A megnövekedett hitelkockázat két formában jelenhet meg: finanszírozási kockázatként és üzleti kockázatként. Finanszírozási kockázat a hitelfelvevô likviditási problémáiból adódik. Ha például egy hitelfelvevő környezetvédelmi bírság fizetésére vagy helyreállítási munkák végrehajtására kötelezett, megnövekszik a pénzügyi kockázat. Magas az üzleti kockázat, ha nem megfelelố a vállalatot irányító menedzsment, ha kedvezótlen a politikai, jogi környezet. Üzleti kockázatot jelenthet, ha az ügyfél elveszíti tevékenysége folytatásának lehetőségét, pl. környezetvédelmi jogszabályoknak való meg nem felelés következtében. 
A biztosíték elértéktelenedésének kockázata akkor merül fel, ha a hitelért folyamodó ügyfél olyan kötelezettségekkel, illetve változásokkal kerül szembe, amikor a felvett összeg visszafizetésére képtelenné válik. Ilyen helyzetben pedig csődeljárás indul ellene, esetleg fel is számolják vállalkozását. Ekkor a fedezetként felajánlott ingatlan a bank tulajdonába kerül, de természetesen minden ahhoz kapcsolódó joggal és kötelezettséggel együtt. Ilyen esetben a banknak kell ügyfele kötelezettségeit teljesítenie. Ha a vállalat csődje valamilyen környezeti károkozás következménye, és a likviditási problémák környezetvédelmi bírságok, helyreállítási, tisztítási kötelezettségek miatt merültek fel, akkor a terület új birtokosát, azaz a bankot terheli a jövớben a felelősség. Ezek a helyreállítási, tisztítási költségek nagyságrendekkel meghaladják a kihelyezett összeg, illetve a fedezet értékét, és a felszámolás költségeinek kiegyenlítésére nem elegendô a felszámolt társaság vagyona. Ilyen esetben a bankok lényegesen magasabb veszteséget szenvednek el anyagilag, mint az egyszerú, be nem hajtható követelések esetében.

A közvetlen felelősség kockázata abból adódik, ha az adott ország jogszabályai olyanok, hogy a hitelnyújtót is felelôssé teszik valamilyen formában ügyfele tevékenységéért. A szigorú felelősség elve akkor jelent kockázatot, ha a jogszabályok kimondják, hogy a hitelnyújtó akkor is felelős, ha nem volt aktív résztvevố a károkozásban, illetve ha részvétele nem volt szándékos. A retrospektív felelősség azt jelenti, hogy a tulajdonos akkor is felelős a károkozásért, ha az a tulajdonba kerülése előtt történt. Vagyis a közvetlen felelősségból következik, hogy a hitelnyújtó felelôssé tehetô a környezetvédelmi költségek akár teljes összegéig, és emellett még a helyreállítási kötelezettsége is korlátlanul fennáll (Kék - Nemcsicsné - Tóth, 1998).

A bankok tehát a környezetkárosító technológiákba, tevékenységekbe való beruházásaik, illetve hitelkihelyezéseik során közvetetten részt vesznek a környezet szennyezésében, miközben ezzel saját kockázatukat is növelik. Az USA-ban és Nyugat-Európában - 7 ország 56 bankjában - végzett felmérés adatai szerint a felmérésben szereplők harmada szenvedett már jelentôs veszteséget környezetvédelmi okok miatt - a legnagyobbakat az amerikai, a német és angol bankok. Az American Bankers Association adatai szerint az USAban a bankok több mint 80 százaléka változtatott hitelezési politikáján, ezen belül majdnem 50 százalékuk teljesen leállította a különösen nagy környezeti terheléssel múködő cégek hitelezését (Hegedús, 1995). Ha azonban a pénzügyi intézmények hitelkihelyezési stratégiájukba környezeti megfontolásokat is beépítenek, a kockázatukat csökkenthetik. Ez további előnyökkel is járhat, például a hírnév erôsítésével és az ügyfélkör bővülésével. Ráadásul a bankok olyan tehetôs befektetối csoportokat vonzhatnak, amelyek számára egyébként nehéz bármilyen más elônyt kínálni. Tehát a fenntarthatósági tényezốk beépítése a banki múködési folyamatokba nem csupán a kockázatot csökkenti, hanem új lehetôségeket nyit meg a pénzügyi intézmény számára.

A green banking tevékenység tehát a bankok és a környezetvédelem kapcsolatát jelenti, ahol a gazdasági hatékonyság mellett a fenntartható fejlődés is éppolyan fontos elv. A zöld pénzügyi intézmények tehát külsô és belsố múködésüket (napi üzem- és üzletmenet, stratégiai célok, beruházási politika, kockázatkezelés) tekintve is tiszteletben tartják döntéseik során a környezetet, annak védelmét és a társadalmi értékeket.

\section{A fenntartható pénzügyi gyakorlat elvei}

Bár a bankok saját érdekükből, racionális piaci szereplóként viselkedve fordultak, fordulnak a fenntarthatóság felé, számos más szervezet a fenntartható fejlődés általános gondolatából kiindulva fogalmazott meg célokat, fektetett le elképzeléseket a fenntartható pénzügyi gyakorlat megvalósítása érdekében. Az 1. táblázat a késôbbiekben bemutatott elvekról nyújt összefoglalást.

\section{Elvek a fenntartható pénzügyi gyakorlatról}

1. táblázat

\begin{tabular}{|c|c|}
\hline \multicolumn{2}{|c|}{ UNEP FI NYILATKOZAT } \\
\hline $\begin{array}{c}\text { Általános elvek a pénzügyi } \\
\text { szektorra vonatkozóan }\end{array}$ & $\begin{array}{c}\text { Banki szektorra vonatkozó } \\
\text { elvek }\end{array}$ \\
\hline $\begin{array}{c}\text { Biztosítótársaságok } \\
\text { nyilatkozata a környezetról és } \\
\text { a fenntartható fejlódésról }\end{array}$ & $\begin{array}{c}\text { Bankok nyilatkozata a } \\
\text { kornyezetról és a fenntartható } \\
\text { fejlódésról }\end{array}$ \\
\hline Rio+10 Finance Commitments & Londoni Elvek \\
\hline Az SiRi Group SRI elvei & WBCSD Nyilatkozat \\
\hline UN Global Compact (PRI) & Equator-elvek \\
\hline
\end{tabular}

Forrás: Saját szerkesztés

Az ENSZ 1972-ben Stockholmban hozta létre környezetvédelmi programját, az UNEP-et. A szervezet 1992-ben hirdette meg az ún. Pénzügyi Kezdeményezést, azaz az UNEP Fi- $t^{1}$.

A fenntarthatóság iránti bankári elkötelezettséget az 1992. évi riói környezeti világkonferenciát követően mindegy 30 kereskedelmi bank által aláírt nyilatkozat erósítette meg. Azóta a nyilatkozat aláírói között több mint 160 pénzügyi intézmény - bank és biztosítótársaság - szerepel. Többségük európai, de az ázsiai régió is jelentős arányban szerepel. A nyilatkozatban foglalta- 
kat 1997-ben banki és biztosítási intézményekre bontottan átdolgozták (1. táblázat). Ezek a dokumentumok rávilágítanak a gazdasági fejlódés és az egészséges környezet elválaszthatatlanságára: az ökológia, a környezet védelme és a fejlődés közös felelősség, amely minden üzleti tevékenység során prioritást érdemel. Az aláírók vállalták, hogy a környezetvédelmi megfontolásokat beépítik a banki, illetve a biztosítási tevékenységbe és az üzleti döntésekbe.

2002-ben, éppen tíz évvel a riói konferencia után, a johannesburgi csúcsra készült el a „The Rio +10 Financial Commitments" dokumentum, amely a társadalmilag felelős befektetésekre, mikrofinanszírozásra vonatkozóan fogalmazott meg alapelveket (Peeters, 2003). Ezek azonban túl általánosak, és lényegében semmi újat nem mondtak a riói világkonferencián elfogadott elvekhez képest, így kevésbé elterjedtek.

A társadalmilag felelős befektetések minél szélesebb körben való elterjesztésére a $\mathrm{SiRi}^{2}$ (Sustainable Investment Research International Group) javasolt intézkedéseket. Külön javaslatok készültek a civil társadalmi intézményekre, a szakszervezetekre, a kormányzatra és a pénzügyi intézményekre vonatkozóan. A pénzintézetek kapcsán hangsúlyozták a fenntartható pénzügyi termékek kifejlesztését, illetve a bankok a pénzügyi elemzéseik mellett társadalmi és környezeti értékelést is végezzenek.

2002-ben brit gazdasági és környezetvédelmi szakemberek tizenegy gazdálkodó szervezettel közösen hét olyan elvet fogalmaztak meg, melyekkel meghatározták az Egyesült Királyság pénzügyi szolgáltatásainak fenntartható fejlódésben játszott szerepét. Ezeket Londoni Elveknek nevezték el. A hét elv három csoportra osztható:

- az első kettô a gazdasági fellendülés jegyében azt hangsúlyozza, hogy a befektetéseknél a lehetô leghatékonyabb eszközöket kell felhasználni, de eközben a vállalat átláthatóságát is biztosítani kell,

- a harmadik, negyedik és ötödik elv a környezetvédelmet helyezi előtérbe, kimondja, hogy a környezetbarát technológiák finanszírozását elő kell segíteni, valamint minden befektetésnél a környezeti és társadalmi kockázatok költségeit is bele kell építeni a pénzügyi termékek - például egy hitel - árába,

- az utolsó két elv szociális aspektusból vizsgálja a kérdést. Egyrészt hangsúlyozza, hogy a finanszírozott tevékenység járuljon hozzá az adott vállalat társadalmi felelősségvállalásához, másrészt leszögezi, hogy a fejlődő országokban is elő kell segíteni ezen elvek terjesztését és megvalósulását.
A Londoni Elvek is meglehetôsen általánosak, nincsenek mögöttuik gyakorlati példák, és hasonlatosak az ENSZ Pénzügyi Kezdeményezés programja által megfogalmazott nyilatkozathoz. Az ENSZ-dokumentum azonban jobban előtérbe helyezi a környezetvédelmet, a Londoni Elvek pedig a pénzügyi szektor szerepét hangsúlyozzák.

Az Üzleti Világtanács a Fenntartható Fejlódésért (World Business Council for Sustainable Development, WBCSD) 1995-ben jött létre a globális környezeti és társadalmi problémák iránt felelősséget érzố vállalatvezetốk kezdeményezésére. A négy pontban megfogalmazott irányelvek amellett, hogy hangsúlyozták a banki szektor közvetítő szerepét, annyiban többet jelentenek az eddigi irányzatokhoz képest, hogy kiemelték: a fenntarthatósági elvek üzleti gyakorlatba történô beépítésével a hosszú távú részvényesi érték növelhető. Az aláírók azt is fontosnak tartják, hogy az átláthatóság növelése érdekében pénzügyi jelentéseiket, beszámolóikat nemzetközi standardok szerint készítsék el.

Az idôben legutoljára kiadott elveket Felelős Befektetések Elvei, azaz Principles for Responsible Investment (PRI) címmel tavaly publikálta az ENSZ Pénzügyi Kezdeményezés és az ENSZ Globális Megállapodás - Global Compact - elnevezésú programja. (Ez utóbbi 1999-ben jött létre, és az üzleti szférát igyekszik szoros együttmúködésre késztetni az ENSZ szervezeteivel.) Az önkéntes elvek egyfajta lehetséges cselekvést nyújtanak arra vonatkozóan, hogy a befektetők környezeti, társadalmi és általános vállalatvezetési elveket építsenek be a befektetési döntéshozatalukba.

Összegezve az állapítható meg, hogy ezek az elvek is túlságosan általánosak, csak a felelős befektetések fontosságát hangsúlyozzák. Bizonyos azonban, hogy az elmúlt 15 évben sikerült lefektetni a fenntartható pénzügyek elméleti alapjait. Az eddig bemutatott, néha túl általános és egymáshoz hasonló elvek mögött azonban tényleges akarat rejlik, ami a gyakorlatban is egyre inkább tükröződik.

A zöld bankok néhány éve keresik a megoldást arra, hogyan fejleszthetnének ki közös és koherens környezeti és társadalmi politikát, illetve olyan alapelveket, melyeket aztán hitelkihelyezéseiknél globálisan és minden szektorra alkalmazhatnak. 2002 októberében Londonban néhány bank a Világbank csoporttal és a Nemzetközi Pénzügyi Társasággal (International Finance Corporation, IFC) megvitatta ezt a témát, és úgy döntöttek, kifejlesztenek egy keretrendszert, melylyel a környezeti és társadalmi kockázatokat érvényesíteni tudják finanszírozási stratégiájukban. E kezdeményezés után 2003-ban jutottak el az Equator-elvek ${ }^{3}$ első verziójához, amelyek az IFC környezeti és társa- 
dalmi politikáján alapultak. A következő három évben az Equator-elveket 50 pénzügyi intézmény adaptálta, majd tanulva a tapasztalatokból, és a külső érintettek (pl. ügyfelek, nem kormányzati szervek) véleményét is beépítve, 2006 júliusában korszerúsítették ezeket ${ }^{4}$. Néhány csoport, amelyek az Equator-elvek alapján végzik finanszírozási tevékenységüket: ABN AMRO, Bank of America, Citigroup Inc, Credit Suisse Group, HSBC Group, Royal Bank of Canada, Standard Chartered Bank, Westpac Banking Corporation.

Az elvek olyan projektek finanszírozásakor kerülnek vizsgálatra, melyeknek teljes tôkeköltsége eléri a tízmillió USA dollárt. Ezek olyan nagy, összetett és drága beruházások, mint az erómúvekbe, vegyipari gyárakba, bányákba történő, vagy szállítmányozási, környezeti, telekommunikációs infrastruktúra javítására irányuló befektetések. Az Equator-elveket minden olyan szektorban globálisan alkalmazzák, ahol jelentós környezeti és társadalmi hatással lehet számolni. A hitelnyújtó bank általában az egyedüli finanszírozó, a hitel nagyságát a vállalat termékeinek/szolgáltatásainak függvényében határozzák meg (például erômúveknél az értékesített villamos energia mennyisége alapján). A hitelfelvevő majdnem minden esetben egy olyan speciális rendeltetésú vállalat vagy vállalati egység, amelynél nem tứr halasztást az adott fejlesztés. A törlesztés elsődlegesen a projekt pénzáramától és a fedezetek értékétôl függ.

Az Equator-elveket betartó pénzügyi intézmények - zöld bankok - csak olyan projektekhez nyújtanak kölcsönt, melyek megfelelnek az alábbi tíz elvnek (Equator Principles, 2006).

1. Vizsgálat és besorolás: Az adott projekt finanszírozása elő́tt a pénzügyi intézmények vizsgálat alá vetik a beruházás társadalmi és környezeti hatásait, valamint pénzügyileg is átvilágítja a céget. Majd a projektet az IFC kritériumai alapján be kell sorolniuk a következó három csoport egyikébe:

- „A” kategória: Ezek a magas kockázatú projektek, tehát azon beruházások tartoznak ide, amelyeknek jelentős káros társadalmi és környezeti hatásai realizálódhatnak.

- „B” kategória: Olyan közepes kockázatú projektek sorolhatók ide, melyeknek korlátozottan lehetnek káros társadalmi és környezeti hatásai. Ezek a hatások szúkebb körúek, mint az „A” kategóriába soroltaké, specifikusak, általában visszafordíthatók, és mérséklő intézkedésekkel befolyásolhatóak.

- „C” kategória: Azon alacsony kockázatú projektek, amelyeknek minimális a káros környezeti vagy társadalmi hatása, vagy egyáltalán nincs.
2. Társadalmi és környezeti értékelés: $\mathrm{Az}$ „A” és a „B” osztályba eső projekteknél a hitelfelvevő részletesen bemutatja a környezeti és társadalmi kockázatokat. Az értékelésnek a projekt jellegének és mértékének megfelelő intézkedéseket is tartalmaznia kell, vagy a káros hatásokra vonatkozóan cselekvési tervet kell készíteni.

3. Alkalmazható társadalmi és környezeti standardok: Az elvek ennél a pontnál megkülönböztetik a nem OECD-országokban, a nem magas jövedelmú OECD-országokban, illetve a magas jövedelmúnek minősített OECD-országokban finanszírozott projekteket. (A három kategória a Világbank meghatározása szerint értelmezendó.) A nem OECDországok projektjeinél, illetve azoknál a projekteknél, melyek nem magas jövedelmúnek minősített OECD-országokban vannak, az értékelés során utalni kell az IFC teljesítménystandardokra és az EHSalapelvekre.

Meg kell vizsgálni, hogy az adott projekt mennyiben felel meg ezeknek, illetve mennyiben jogos az ezektôl való eltérés. A magas jövedelmú OECDországok követelményei általában megegyeznek, vagy meghaladják az IFC teljesítménystandardok és EHS-alapelvek követelményeit. De az értékelési folyamatnak mindkét esetben az adott ország aktuális jogszabályaiba, szabályozásába és engedélyezési rendszerébe kell illeszkednie a fentiek figyelembevétele mellett. Az IFC nyolc teljesítményszabványt állított fel, melyek a következókre vonatkoznak:

- társadalmi és környezeti értékelőrendszer,

- munkafeltételek,

- környezetszennyezés megakadályozása, csökkentése,

- egészség és biztonság,

- földvásárlás és kényszerú helyváltoztatás,

- biodiverzitás megőrzése és fenntartható természeti erőforrásokkal való gazdálkodás,

- őslakosok,

- kulturális örökség.

Ezeken a standardokon belül azt fogalmazzák meg, hogy a szervezeteknek milyen feltételeknek kell megfelelniük. Az iparspecifikus környezetre, egészségre és biztonságra vonatkozó alapelveket (EHSalapelveket) lényegében két, egymást kiegészítő csoportra bonthatjuk. A Világbank a Szennyezés megakadályozása és csökkentése címú kézikönyvében sorol fel 41 ipari tevékenységet, míg az IFC további 28 szektort különböztet meg. Minden egyes ipari szektorra megadott környezetvédelmi mutatók 
alapján számított határértékek és különleges szabályok ${ }^{5}$ vonatkoznak, melyeket az adott szektor finanszírozásakor ellenőrizni kell.

4. Akcióterv és irányítási rendszer: Az „A” és „B” osztályú projekteknél a hitelfelvevőnek egy akciótervet kell készítenie. Az akcióterv tanúsítja és rangsorolja a negatív hatásokat, mivel ez szükséges azok csökkentéséhez, majd szemlélteti a javító intézkedéseket. Mindezek szükségesek ahhoz, hogy a kockázatokat és hatásokat pontosan azonosítani tudják az értékelés során.

A hitelfelvevố vállalatnak létre kell hoznia egy társadalmi és környezeti menedzsmentrendszert, amenynyiben még nem rendelkezik ilyennel. Ez tehát a hatások, kockázatok, javító intézkedések menedzselése, amely úgy történik, hogy közben betartják az adott ország társadalmi és környezeti jogszabályait, a teljesítménystandardokat és az EHS-alapelveket. A magas jövedelmú OECD-országok projektjeinél, az elveket aláíró bankok kérhetik egy akcióterv kifejlesztését, mely megfelel a megengedett szabályoknak, továbbá az ország törvényein alapul.

5. Konzultáció és közzététel: Azoknál az A és B kategóriájú projekteknél, amelyek nem OECD, illetve alacsony jövedelmú OECD-országokban vannak, a kormányzat, a kölcsönvevô vagy egy harmadik szakértố is konzultál a projektet érintố közösségekkel. Mindezt strukturáltan, az adott kultúrának megfelelő módon kell megtenni. A konzultációnak belsố manipulációtól, beavatkozástól, kényszerítéstól és megfélemlítéstốl függetlennek, naprakésznek kell lennie, emellett az aktuális, valós információkat kell közölni érthető és hozzáférhetô módon. A konzultációnak folyamatosnak kell lennie, és az adott ország nyelvén elérhetôvé kell tenni a beruházásról készült dokumentumokat, például az akcióprogramot, vagy a projekt értékelését bemutató iratokat. A kölcsönvevônek figyelembe kell vennie és dokumentálnia kell a konzultáció folyamatát és eredményeit is.

6. Nézeteltérések tisztázása: Az „A” és „B” minősítésú befektetéseknél biztosítani kell, hogy a befektetés által érintett közösséggel történő tanácskozás és az ennek eredményeképpen megszületett dokumentumok közzététele folyamatos legyen. A lakosság meghallgatása után az esetleges nézeteltéréseket a kölcsönt felvevőnek kell tisztáznia és megoldania. Ennek eredményeiról is azonnal és valósan, az adott kultúrának megfelelóen tájékoztatni kell az érintetteket.

7. Független felülvizsgálat: $\mathrm{Az}, \mathrm{A}$ ” és „,B” minősítésú projekteknél egy független, társadalmi és környeze- ti szakértő kapcsolatban áll a kölcsönt felvevővel, és felülvizsgálja az értékelést, az akciótervet, valamint a konzultációs folyamat dokumentumait. Ezzel támogatja az elveket aláíró bank pénzügyi átvilágítási munkáját és az Equator-elveknek való megfeleltetést.

8. Kötelezettségvállalás: Az „A” és „B” osztályzatú projekteknél a hitelfelvevố a pénzügyi dokumentációiban ígéretet tesz, hogy:

- betartja az adott ország aktuális társadalmi és környezeti jogszabályait, előírásait és engedélyeit minden jelentôs tekintetben,

- teljesíti az akcióprogramot a projekt kivitelezése és a projekt múködése alatt,

- rendszeres jelentést ad, melyet a cégen belüli menedzsment vagy egy külső szakértő (harmadik fél) készít el, és ennek meg kell felelnie az akciótervnek, helyi törvényeknek, szabályozásoknak, engedélyeknek,

- egy leszerelési tervnek megfelelóen megszünteti a felesleges üzemeit.

Ha a hitelt felvevő nem tartja be a társadalmi és környezeti kötelezettségeit, a pénzintézet figyelmezteti oót egy még elfogadható szintú teljesítésre. Amenynyiben azonban a hitelfelvevőnek ezúttal sem sikerül a teljesítés egy adott türelmi idő́n belül, a bank élhet jogorvoslati jogával.

9. Független ellenôrzés (monitoring) és jelentés: lényeges szempont, hogy a kölcsön ideje alatt biztosított legyen a folyamatos monitoring és a jelentések közzététele. Ennek érdekében az „A”, és amenynyiben lehetséges, a „B” minősítésû projekteknél egy külsô, független környezeti és/vagy társadalmi szakértốt kérnek fel a beruházás ellenôrzésére. Előírhatják továbbá, hogy a cég tartsa meg a független szakértót, hogy az folyamatosan ellenórizze azokat az információkat, melyeket a vállalat a bankkal is megoszt.

10. A bank jelentése: minden banknak évente legalább egy jelentést kell publikálnia arról, miként valósítja meg az Equator-elveket, illetve hogy mindeközben milyen tapasztalatokat szerzett (Equator principles, 2003).

Az elvek két részre oszthatók az alapján, hogy kinek a felelősségi körébe tartoznak. A bank felelőssége az 1, $3,7,8,10$. elvek teljesülése; a hitelfelvevő felelőssége a 2, 3, 4, 5, 6, 9. elvek megvalósítása, betartása.

Az Equator-elvek hátránya, hogy csak nagyberuházások finanszírozására vonatkoznak, számos elvet azonban át lehet ültetni kisebb összegú beruházások fi- 
nanszírozási gyakorlatába is. A bankok a vállalkozások C típusú beruházásaihoz nyújthatnának zöld hitelt, azaz olyan befektetésekhez, melyeknek nincsenek káros társadalmi és környezeti hatásai. Mindezt a vállalatoknak kell prezentálniuk hitelkérelmük benyújtásakor. Igen jó lehetőség erre, ha egy vállalat fenntarthatósági jelentést ad ki, azaz pénzügyi teljesítménye mellett környezeti és társadalmi teljesítményét is prezentálja. Ma már vannak olyan nonprofit szervezetek vagy tanácsadó cégek, melyek független szakértốként auditálják a vállalatok környezeti teljesítményét, minôsítik fenntarthatósági jelentésüket. Ezáltal a független monitoring elve is teljesíthetô.

\section{Összegzés}

A green banking a bankok és a környezetvédelem kapcsolatára utal, amelyben a legfontosabb vezérelv a fenntarthatóság, és amely a fejlődés egy olyan formáját vetíti elő, ahol a környezet a gazdasági realitásokkal összeegyeztethető és társadalmilag is elfogadható. A gazdasági élet szereplói számos alkalommal szorulnak külső, banki finanszírozásra, amely során a zöld bankok ma már olyan beruházásokat finanszíroznak, amelyek figyelembe veszik a környezetvédelmet, azaz nemcsak a gazdasági hatékonyság az egyetlen fó cél, hanem a társadalmi és környezeti, környezetvédelmi céloknak való megfelelés is. Finanszírozási szempontból a bankok tehát aktív partnerek lehetnek a fenntartható fejlődés elérésében. Ehhez segítséget nyújtanak, és egyfajta keretet adnak az Equator-elvek, amelyek szükséges, de nem elégséges alapot teremtenek a bankok döntéshozatali folyamata során. Nem elégséges, hiszen ezek az elvek túlságosan általánosak, nagyberuházásokra vonatkoznak, de kiindulópontként szolgálnak, amennyiben nemcsak látszólagos a hajlandóság a gazdasági élet szereplői között a környezet aktív védelmére. Eddigi vizsgálataink egyfajta külső szemléletmódot követnek, melyek az általános banki fenntartható múködési normák alapját teremtik meg. Ugyanakkor szükségessé válik e tényezốk operacionalizálása a banki teljesítménymutatók rendszerén keresztül. Alapvetô kérdés ugyanis, hogy milyen mutatók alkalmazásával lehet egy banki tevékenységet zöldnek minősíteni, és hogyan lehet kimutatni a zöld tevékenységek folytatásának életképességét, gazdasági előnyeit. Ez pedig egy korrekt, nemzetközi szinten is elfogadható indikátorrendszer felállítását teszi nélkülözhetetlenné.

\section{Lábjegyzet}

${ }^{1}$ Az UNEP FI program keretében 1994 óta évente rendeznek konferenciákat, kerekasztal-tárgyalásokat. Munkacsoportok jöttek létre különbözó kiemelt témákhoz kapcsolódóan, melyek eredményei publikálásra is kerülnek.

${ }^{2}$ www.siricompany.com

${ }^{3}$ www.equator-principles.com

${ }^{4}$ Az elveket elfogadó pénzügyi intézmény nem aláírással hitelesíti az egyezményt, hanem nyilatkozik arról, hogy belsó politikájába, ügyrendi szabályzatába és folyamataiba beleilleszti az Equatorelveket.

${ }^{5}$ http://www.ifc.org/ifcext/cnviro.nsfyContent/EnvinnentalGuidelines

\section{Felhasznált irodalom}

Deutsch, N. - Pintér, É. (2007): Note on the relationship between sustainable development and marketing in the banking sector. Marketing és Menedzsment, XLI. évfolyam, 6. szám, p. 85-94.

Flatz, A. (2000): Umweltschutz im globalen Wettbewerb. Berliner Konferenz, Berlin

Hegedüs Gy. (1995): A kereskedelmi bankok és a környezetvédelem: Az átfogó környezettudatos vállalatirányítás lehetôségei Magyarországon. Konferencia Kötet, INEM, Budapest

Holdren, J.P. - Daily, C. - Ehrlich, P.R. (1995): The Meaning of Sustainability: Biogeophysical Aspects. In: Munasinghe, W. (ed.): Defining and Measuring Sustainability: The Biogeophyiscal Foundations. World Bank, Washington, DC

Kék M. - Nemcsicsné Zs. Á. - Tóth G. (1998): Zöldülő bankok, Bankszemle, 1998/1-2. 73-88.o.

Tóth G. (2001): Környezeti teljesítményértékelés. Környezettudatos Vállalatirányítási Egyesület, Budapest

Cikk beérkezett: 2010. 12. hó

Lektori vélemény alapján véglegesítve: 2011. 2. hó 